\title{
Appreciation of Igbo Folktales and Songs Versus Realism
}

\author{
Uche Janet Ogbalu \\ DOI: http://dx.doi.org/10.4314/ujah.v12i1.3
}

\begin{abstract}
Igbo folktales are fiction. Folktales are regarded as fictitious, senseless and totally devoid of truth and reality and totally removed from real life situation and events. Nevertheless in their functionality, one discovers that folktales exhibit some elements of truth that somehow translate them into realism and true life situation. For instance while appreciating folktales, real people laugh, shout, cry, hiss, and clap hands as if in real life situation. An observation of folktale story telling sessions shows that Igbo people are so much attached to this literary genre. The author feels that there must be some natural compelling forces behind this phenomenon which make Igbo people appreciate their folktales (fiction) as if they were true life stories. This paper identifies and discusses these forces that make Igbo people appreciate their folktales so.
\end{abstract}

\section{Introduction}

Igbo folktales by their nature as well as their definitions are regarded as fictitious, fabulous, mythical, totally removed from real life situation and events. In their appreciation in actual life performance, one discovers that folktales exhibit some elements of truth that somehow translate them into realism and true life situation. This accounts for the reason why real people on their appreciation react to them as if they are real life stories. Besides a careful observation of the folktale performing sessions show that neither the performer nor his audience is ready to move out of the scene. None shows sign of getting tired of either telling the story or 
listening to the story. The folktale narrator is able to hold his audience for hours or even days without the audience getting tired. Folktales are introduced to a traditional Igbo child from infancy. This means that the traditional Igbo child starts appreciating folktales from infancy to adulthood. Apronti advancing reasons why people have invested on folktales says "A literary type such as folktale owes its vitality to the fact that the distinction between narrator and audience is blurred, thus making audience participation a condition for successful realization of the type" (le in full realization of folktales as an aesthetic experience. In performance, the audience participation is assured. The audience sings the chorus, claps hands and even corrects the performer whenever he deviates from the normal routine of the story. That is why one can rightly assert that folktales are communally owned.

\section{Functions of Folktale}

No one can exactly say when Igbo folktale originated but one thing is certain, the folktale is as old as the society it belongs to. Folktale stems from man's desire to communicate his experiences to others, to let others share his views about life, to direct members of the society, to satirize deviant characters in the society and to instill the spirit of love for the community amongst members of the society. It is interesting to note that the folktale narrator lives in the community with others. He takes materials for his tales from his experiences in the community so the events of Igbo folktales are not strange to his audience. Igbo folktales contain the people culture, world-view, norms, spiritual life, their hopes and aspirations. In short Igbo folktale contains Igbo man's total way of life. It is the recreation of the folk's activities in the society. 
One of the functions of Igbo folktale is education. Nwaozuzu aligns that: "The widespread of human tendency to teach, entertain and satirize by indirect means seems to be at the root of the evolution of folktales" (p. 28). Igbo folktale is used to educate both the young and the aged. It contains folk's skeptical views about life which are based on their observation of people's behaviour in the society. It inspires the young and provides moral standard cherished by their society. It also directs members of the society on the right action to take in case of emergency. It provides them a common line for their action. Since Igbo folktale mirrors the activities of members of the society, it means that the problems and successes embodied in their folktale are the problems and the successes of the society. That is why Ashton has it that, "the introduction of folkways in folktales is merely to give verisimilitude to a depiction of life of a particular locality" (p. 20). This introduction of folkways in folktale implants realism in the folktale and makes for easy comprehension of the folktale.

Another function of folktale is entertainment. Folktale is normally told in the evening after the evening chores. Children normally sit round the fire side in their father's "obi" or in their mother's hut to listen to folktales. Normally the elders, their father or mother tells the story. Children then take turns in telling their own stories. In some cases, children are grouped to compete in proverbs, riddles and tongue twisters. At the end of this competition the winners are happy. These are aimed at preparing them for their adult life. It is important to note that proverbs, riddles and tongue twisters are introduced to the children to make them speak fluently as orators who will be future representatives of their society on any occasion.

These story telling sessions normally take place in the evening after the evening chores. They take place in the 
relaxed atmosphere unlike today's education which is characterized by strictness and rigidity. Traditional Igbo child listens to the folktale from infancy to adult life. By the time he gets to adult life, the events of the folktale had entered into the morrow of his bones. This means that he is firmly rooted in his society's way of life. This will continue to direct his life throughout on earth. That is, folktales serve for the execution of the biblical injunction "train up a child in the way he should go, and when he is old, he will not depart from it" (Proverbs 22 vs 6). This means that once a child is properly rooted in the lore of his people, he is firmly rooted in the sound moral upbringing and the total way of life of his people and will therefore not depart from this education when he grows up.

It is a common feature in Igbo folktale to intersperse or punctuate the story with songs, these songs help to enliven the narrative. Obiechina affirms that "song not only heightens the narrative but also vivifies it. It also ensures audience participation. Song is used to illustrate and emphasize a point in the story telling. Song also helps to ensure the alertness and attention of the audience, as well as providing them with some respite or digression as the story progresses" (p. 47).

Achebe acknowledges that the song in the folktale Nwoye's mother was telling Nwoye (her son) had emotional impact on Nwoye; "Nwoye felt carried away to the distant scene in the tale where the vulture ... sang for mercy" (p. 38). The song has emotional impact both on the performer and her audience. This is achieved because as Onyekaonwu rightly asserts:

In oral traditional story telling, two main aspects of performances are pursued. These are the physical performance aspect (usually visual) and the verbal or oral performance aspect (usually acoustic) (p. 230). 
This follows that sight and auditory senses play a great role in the full realization of the aesthetic value of the tale being rendered. The humble appearance of Nwoye's mother and the beauty of her voice were the main forces that touched her son's emotion. In addition, in the case of the vulture singing to the sky, the vulture's beauty of voice moved the sky to pity and he sent rain to the earth. Okpewho acknowledges that:

Because the experiences and expectations of the society are woven round the events of the folktales, the suspension of disbelief by the audience is an easy one, this also accounts for their instant correction given to performer when he deviates from the normal routine of the tale or normal way of telling the story (p. 161).

The events of these stories are introduced to Igbo child right from infancy. This means that the traditional Igbo child learns to suspend his disbelief in appreciating the events of folktales right from infancy and so grows with it. Emenyonu affirms that:

The bond of affection between mother and child in the Igbo culture is a very strong one, especially when the child happens to be a son. When the dishes of the evening meal have been washed ... children sit round the fireside to be entertained by the mother till bed time (p. 3).

Ogu commenting on the impact of story telling session on traditional Igbo child says:

1. It gives the child the opportunity of using imagination to decipher the truth and develop his intellectual ability. Their wits are tested by allowing them give quick answers to questions posed to them. 
2. It helps the child develop creative thinking as a natural process through which a person becomes aware of a problem, difficulty or gap in information for which he has no previous knowledge.

3. Obedience and respect are other contributions of folktale to children development. Most stories and songs condemn bad behaviour. In African folktales good always triumphs over evil, truth over falsehood, honesty over dishonesty.

4. National consciousness and patriotism are inculcated into the child with the aid of folktale. Children learn bravery, selflessness etc from legendary stories and songs that tell how heroes suffered greatly or even died for their people. Children were attracted to such characters and usually they aspire to be like them. Legendary stories give the child an undiluted insight into the history of his society. This type of story embodies the values, fears and assurances of the people who invented them.

5. Every story has a lesson to teach just as the stories about heroes and heroine encourage children to be brave in the defense of their society (p. 22).

Folktale is used to satirize the deviant characters in the society thereby making them change their bad behaviours for good. For example, a wayward girl or woman in the society can be satirized.

A woman who maltreats an orphan is satirized. Equally a man that beats up his wife or who neglects his family responsibility is satirized etc. Through satire, the society maintains its codes of conduct.

\section{Characteristics of Folktales}

Folktales as fiction make use of characters in telling the tales. Emenanjo asserts that, "one can say that all the characters in 
folktales, be they animals, spirits or human beings are stock character. For very often each character represents a motive in the frame work of the tale" (p. xv). Emenanjo cautions that the characters in the folktales should not be judged in terms of realism as people understand them to be in creative work because these characters rarely grow to become 'rounded'. Forster adds that the characters are "constructed round a single idea or quality" (p. 73). The characters in folktales are created to illustrate a point and the view of the author. For example, tortoise is a symbol of injustice, greed and wickedness. In most cases, tortoise is used to illustrate the Igbo man's belief in retributive justice, o metara buru, 'whatever one sows that he will reap'. Lion has the image of force, the spider symbolizes avarice, bees and ants portray hard work and industry, child is a symbol of innocence and credulity, rhino for monstrosity, elephant for unruffled strength, hugeness and the ultimate in any series, hawk is the indicative of agility and ruthlessness, eagle represents beauty and excellence while ram is the stock figure for strength and extreme endurance and so on.

One of the outstanding qualities of folktales throughout the world is the possessor of trickster hero. Okpewho referring to trickster says:

Tricksters represent what is feared but secretly
coveted...tricksters may be condemned for
moral depravity, selfishness and lack of a sense
to reciprocity, but on the other hand, they may
inspire a mild sense of administration for their
wit, craftiness and ability to achieve the
seemingly impossible (p. 263).

Various communities of the world have specific names for their tricksters in their folktale. In Igbo it is tortoise 'mbe', in 
Hausa, it is 'ereke' the bush rat, in Yoruba, it is 'Ijapa' the tortoise, in Ashanti, Ghana, it is 'ananse', the spider, in Trinidad, fox and in various parts of Europe, fox, rabbit or hare. Commenting on physical appearance of these tricksters, Emenyonu asserts that; "these tricksters are handicapped by their physical limitations" (p.1) but they are able to escape from tight situations by resorting to a number of cunnings to outwit adversaries. These tricksters are representatives of the characters in the society.

In Igbo traditional society, 'mbe', the tortoise, represents a very puzzling character. $\mathrm{He}$ is both a representative of what is very highly valued and what is selfish, greedy and wicked. He represents breach of reciprocity of norm which is aka nri kwoo aka ekpe, aka ekpe akwo a ka nri 'one good turn deserve the other. Igbo people highly believe in this principle. In one of the stories, the tortoise borrowed some money from his friend, the pig and promised to pay back on the appointed day. He defaulted several times until the pig got angry and threw away the tortoise wife's 'grinding stone' not knowing it was the tortoise. The tortoise quickly came out to demand for the grinding stone. According to him, that was where he kept the pig's money. The pig quickly ran out to look for the stone. This is used to illustrate that the tortoise never pays his debt. This accounts for the reason why the pig continues sniffing at the ground to this day looking for the grinding stone. Tortoise outwits all the animals in all their engagements. Tortoise is however a role model for bringing up children to act in a way approved in the Igbo world view. It is expected that one should come out of trouble by hook or by crook just as Obinna in Ubesie's Juo Obinna (1977) had escaped from conscription into the army by pretending to be an artillery shock victim. 
Igbo folktales have two temporal settings; the setting can be either in natural or supernatural world. The events could take place in human world or in the land of the spirits or in the heavens or even in the rivers. Folktale has stereotype formal opening and closing. The opening can be o ruru otu mgbe 'once upon a time' otu ubochi 'one day'. It can also begin with, chakpii.... woo. In the end, the lesson derived from the tale is either announced to the children or they are left to say the lesson by themselves.

Folktales generally have themes and motifs. Onyekaonwu explaining the reason for the existence of numerous themes and motifs in Igbo folktales says "it is because folktales are invariably didactic in purpose; it teaches one moral lesson or the other which is reflected in the tale. The tales contain the people's code of conduct, world view, customs and way of life" (249). The stories operate through such themes as 'evil acts do not pay', 'orphans should not be maltreated', 'disobedience brings suffering, and kindness brings fortune' etc. The stories operate through such motif as 'the wicked step mother motif', 'the wicked co-wife motif', the benevolent spirit motif, 'lack of male child motif' etc. Through these numerous themes and motifs, folktales mirror the activities of the societies or the activities of members in the society.

Because of the important role which folktales and songs continue to play in traditional society, Dorson remarks; "today, it is recognized that folktales and myths are not simply told, they are performed by the narrator and his audience, the performer utilizes images and patterns to evoke emotions in the audience" (p. 49). Dorson rightly observes that folktales and myths are being performed by minstrels and bards because it is only through performance that the full aesthetic qualities of the story can be fully realized. In other 
words it is only through performance that folktales and myths can be fully appreciated.

\section{Appreciation of Igbo Folktales and Songs}

Fiction is concerned with the presentation of imaginary events and the portraiture of imaginary characters in imaginary world setting. It therefore follows that the work of fiction is not real life story. Igbo folktale is fiction and so both the characters and the events portrayed in the folktale is imaginary and devoid of truth. There are two types of fiction. They are realistic fiction and non-realistic fiction. In realistic fiction, the events of the story normally follow the pattern things occur in real life. In this type of fiction, the appreciation of events of the story is direct. In the nonrealistic fiction, the events portrayed in them occur in a manner far removed from the way they naturally occur in nature. In this type of fiction, the appreciation is indirect. Example of realistic fiction is Ubesie's Juo Obinna Example of non realistic fiction is folktales. In folktales man, animal, bird, spirit, in short animate and inanimate objects interact with human beings.

For one to appreciate the events of the folktales, willing suspension of disbelief is required on the part of the appreciator. One should willingly suspend all doubts; that is, all double minds about the events of the story being true or not and be ready to accept everything that happens in the tale as true. Once the appreciator is able to set all doubts aside, and accepts all he sees as real, these things he has accepted as real generate some magical powers and influence him to emotionally respond satisfactorily to the stories.

The appreciation of any work of fiction has two levels. Each of these levels of fiction appreciation has its own characteristics which distinguishes it from the other level. 
These levels of appreciation enable the appreciators respond to the events presented in the story in a desired or anticipated manner. Affirming this assertion, Di Yanni, has it that:

\begin{abstract}
When we read a literary work, something happens to us. A poem may provoke our thinking, evoke a memory, and elicit a strong emotional response. A short may arouse our curiosity about what will happen, engage our feelings for its characters stimulate our thought about why things happen as they do. A play may move us to link its dialogue and actions with our lives (p. 7).
\end{abstract}

When one reads or listens to fictitious story, there is a type of feeling or impact it makes on the appreciator. This feeling makes the appreciator react voluntarily or involuntarily to the story. They are voluntary appreciation and involuntary appreciation.

\title{
Voluntary Appreciation
}

The voluntary appreciation is the type of appreciation that occurs when an appreciator has willingly suspended his doubt or his disbelief and accepted all he saw as the truth. In this respect, Okpewho observes that:

Much more frequently in his performance, however are those instances in which the bard seems to carry the audience along by the effective force of his speech and act so that they react favorably with expressions such as laughter, grasping and ululation. Whether in these instance the bard touches them with an emphatic recognition of images which are part 
of the stock of their cultural life, or successfully sweeps them off the grounds of reality so that they accept the fantasy of his portraits, there is no doubt that he has made a mark (p. 164).

This follows that once one has willingly suspended his disbelief and accepts all he sees as the truth, his resolve will generate some magical influence on him and he is completely swept off the world of reality to the world of fantasy where he is completely overwhelmed by the events presented in the story. He finds it difficult to distinguish between the real events and fictitious events and so accepts all he sees as the truth. He therefore responds to the story as if the story is true and real whereas there is no truth in the story. It is just fiction.

This force that enables him to see truth in the work of fiction is the force of verisimilitude or the force of probability of truth in fiction. No matter how unrealistic, how fantastic the work of fiction is, verisimilitude has a way of linking it with reality. Willing suspension of disbelief occurs before verisimilitude can take place in fiction.

It is the combination of willing suspension of disbelief and the force of verisimilitude that gives rise to the two forms of responses witnessed on the part of the appreciator. It is also the duty of the oral performer or the literary artist to inculcate such materials, such techniques that reflect reality which will in turn enable the willing suspension of disbelief and the verisimilitude to occur.

In voluntary response, the appreciator controls his emotion, he controls his actions, in the case of the above extract (p. 11), because the appreciator willingly suspended his disbelief and has thus been transported to the world of fantasy, he is responding voluntarily with laughter, grasping and ululation. In some other cases, he responds by calling the 
performer his praise names. Urging him and gingering him on. He sprays money on him to show his utmost excitement. He dances, claps his hand. All these go to portray his emotional response which in turn shows that the performance is successful.

One the effecst of fiction, Meyer affirms that:
An effective literary work seems to speak directly to us... the inner life that good writers reveal in their characters often gives us glimpse of some portion of ourselves, we can be moves to laugh, cry, tremble, dream, ponder, shriek or rage with a character... Although the experience itself is imagined emotion is real (p. 4).

Though the work of fiction is imagined, it has considerable influence on real human beings, one responds to the events of events of fiction as if it is real life story. Eliot affirms that: "the fiction we read affects our behaviour towards our fellow men, affects our pattern of ourselves. When we read of human beings behaving in certain ways, we can be influenced towards behaving in the same way" (49). In like manner when we listen to folktales, the characters in folktales also affect our real character. For example Obinna Ubesie's Juо Obinna is influenced by the character of tortoise in Igbo folktale.

It is the combination of the willing suspension of disbelief and the appearance of truth in the work of fiction otherwise known as verisimilitude that make adults sit with children round the fire place to listen to and appreciate the events of folktales such as "how tortoise used a grain of maize to marry the king's daughter and both of lived together and bore children". How osa the squirrel brought an old woman as his mother for the animals to kill whereas his real 
mother, was securely kept in the sky by the squirrel, "how Ojaadili, the great wrestler travelled down to the world and wrestled with his chi his creator", "how birds, rivers, streams, trees and animals interact with human beings". It is an indisputable fact that those stories do not only appeal to children alone but they also appeal to adults as well even in this world of jet age and modern technology.

\section{Verisimilitude}

Verisimilitude is the probability of truth and realism in something that is not real. Fiction on its own part is those species of literature which are concerned with the presentation of imaginary events and the portraiture of imaginary characters in imaginary world and in imaginary setting. Fiction is that story created out of the authors imagination and there is no truth whatsoever in the story. Just as has been discussed earlier, the fiction narrator lives in society with other members of the society. He has motive for telling his story. His motives might be to instruct, to direct, to praise, to satirize, to inform and to educate members of his society. The motive moreover, might be to preserve the culture and the world view of his people and project them to other wider societies. The experiences of the society are interwoven in his story. That is why it can be said that literature mirrors the activity of the society.

It is therefore the duty of the appreciator to think about the message of the story, digest the story, in order to arrive at the message of the narrator and relate his message to the life in society. The artist on his own part should narrow the gap between the world of fiction and the world of realism. Meyer in support of this view asserts that "both the (appreciator) and the author (the artist) create the literary work. How a reader responds to a story...will help to determine its meaning" (p. 9). 
The relationship between fiction and verisimilitude stems from the fact that fiction presents imaginary events with characters in imaginary setting and with imaginary plot. Verisimilitude, on its part, foresees events presented in fiction as real whereas there is no truth in them.

For non-realistic fiction to be meaningful a lot of work is required on the side of both the artist and the appreciator. Whereas the artist presents his story in such a manner to resemble the way things happen in real life, the appreciator should appreciate the story as such and understand the artist's point of view. This is because, as Walton aligns:

The barrier between the two worlds is not air tight... there are epistemological holes in it...

We respond to what we know about the fictional world in many ways that we respond to what we know about the real or at least it seems (p. 12).

The holes are the link or the bridge connecting the fictional world with real world. This "link" or bridge is the verisimilitude which enables the appreciator see realism in the work of fiction. The closeness of fiction to the events of real life quickens the occurrence of suspension of disbelief and enhances occurrence of verisimilitude. Iser acknowledges that "fiction is a means of telling us something about reality. Verisimilitude is therefore an indispensable factor in appreciation of non-realistic fiction" ( 7). Verisimilitude is responsible for the continued appreciation of the events of Igbo folktales and songs by the people of various ages-adults, children, young, old, educated and non-educated. 


\section{Involuntary Appreciation}

Whereas in voluntary appreciation, the appreciator willingly sets aside his disbelief in that work of fiction before the truth encapsulated within that work of fiction is realized. In involuntary appreciation, the appreciator is no longer in control of his actions.

In watching the play Ojaadili, Ojaadili was admired as a great wrestler who had defeated both human beings and spirits. When Ojaadili opted to wrestle with his chi, his personal god, his friends and relations pleaded with him not to carry out such actions Ojaadili persisted and wrestled with his chi. At that point of wrestling, people in real life - the appreciators were shouting aloud showing their withdrawal of their support and sympathy for Ojaadili. In Igbo traditional belief, no one is expected to challenge his chi which is much more superior to the individual. The appreciators were shouting showing their resentment against Ojaadili's action as they would do in real life situation forgetting that what they were watching is just an imitation of action. The effect of verisimilitude enabled them to act like that because they have perceived realism in the play while the play is just fiction. Ilogu referring to this 'chi' says:

At the time of birth, ...Chukwu gives to each man a part of his divine nature called "chi" which becomes the spiritual double of the man throughout his life. Whatever abilities, good or bad fortunes, successes, failures or weaknesses possessed by the man are often attributed to his 'chi' (p. 36).

That is the reason why people in real life join the characters in drama to withdraw their support against Ojaadili's action. At his defeat, the appreciators just sigh and 
regard him as a foolish and stupid man. Involuntary appreciation is commonly seen in drama. For example in Onyekaonwu's Nwata Rie Awo, when Aworo kills himself, the sight of blood made the appreciators join the actors in shouting, crying and screaming as if the action is real but Aworo is just acting. Involuntary appreciation is emotion based and it occurs mostly in drama and in other visual performances. For example, it is always normal to hear that at the end of Nigerian International Soccer Competition that some one jumped from a height and crashed to the ground. His action might be motivated by emotion of joy for the country's victory or sadness for the country's defeat. Such action is involuntary. During such football contest also, one who is so absorbed in the game may continue to direct the players in the field without realizing that he is only watching the image of the match on the television.

Realism is concerned with the presentation of imaginary or fictitious events in such a way that they resemble the way things happen in real life. This manner in which fictitious characters cause real people to have sleepless nights, shed tears, laugh, and scream as they appreciate work of fiction is one of the ways realism in Igbo fiction and in all works of fiction is realized. In most cases in drama, the role played by an actor affects his reputation in real life. For example, a step mother who maltreats an orphan in drama is likely to attract cynical remarks concerning the role she has dramatized. They may hate her because of the role she has played. On the other hand a person who played the role of a good Samaritan in drama is loved because of his action in the drama. People in real life often forget that these roles these people play in drama are feigned. They are just acting. 


\section{Conclusion and Findings}

Igbo folktales and songs mirror the activities of Igbo society. It therefore follows that the activities of the society are recreated in the peoples' folktales and songs. Various themes and motifs of the folktales are taken from experiences of real life activities of the society. The materials or the items mentioned in the folktales are the items in real life society. The characters in the folktales are the characters in real society. The problems handled in the folktales are the problems of real life society. The joy of the folktale is the joy of the real life society. Igbo folktales and songs are therefore an embodiment of Igbo man's culture, worldview, and his religious belief, his political and social activities and in short, his total way of life. For this reason, Igbo people are so much attached to this literary genre and consequently their addiction to them. One can rightly assert that Igbo folktales and songs are therefore an integral part of Igbo man especially those born and nurtured in Igbo traditional way of life.

In addition to the above, these folktales and songs were often introduced to the children at a very tender age. The stories and songs were held in a relaxed atmosphere. These folktales and songs have therefore; become part and parcel of their lives even in their adult lives. The events of the folktales and songs educate them, direct their actions, entertain them and also inculcate the spirit of nationalism and patriotism in the children. The events of the folktales and songs have therefore entered the marrow of their lives and so they are so much attached to the folktales. Folktales and songs continue to direct their lives wherever they are found in their adult lives. This also accounts for the reason why the adults and children are endeared to folktales and songs.

The force of willing suspension of disbelief also play active role in sustaining Igbo people's interest in their 
folktales and songs. Events of the folktales are unrealistic, non imaginary and devoid of truth but with Igbo people's willing suspension of disbelief, they accept the stories of folktales as the reality. For willing suspension of disbelief to occur in a work of fiction, the events of the story must reflect reality and so the events of folktales and songs reflect reality. 


\section{References}

Abram, M. H. A Glossary of Literary Terms. New York: Rinehart and Winston 1957.

Achebe, C. Things Fall Apart. London: Heinemann 1858.

Apronti, E. O. "Writer in Our Society" in Nwoga D. (ed) Literature and Modern West African Culture. Benin: Ethiope Press 1978.

Ashton, J. N. Folklore in the Literature of Elizabeth England. Bloomington: Indiana University Press 1957.

Di Yanni, R. Reading Fiction Poetry and Drama. New York: Mc. Graw-Hill 2002.

Dorson, R. M. Folklore in the Modern World Hague: Mauton Publishers 1978.

Eliot, T. S. "Religion's and Literature" in Scot, W. (ed) (1979) Five Approaches to Literary Criticism. London: Macmillan 1979.

Emenanjo, E. N. (ed) Omalinze, Book of Igbo Folktales. Ibadan: Oxford University Press 1977.

Emenyonu, E. Literature and National Consciousness. Owerri: Heinemann 1989.

Forster, E. M. Aspects of the Novel. New York: Pelican Books 1927.

Ilogu, E. Christianity and Igbo Culture. Enugu: Nok Publishers 1974.

Iser, W. The Reality of Fiction; A Functional Approach to Literature: A New Literary Interpretation. Vol. vii No 11975.

Meyer, M. The Bedford Introduction to Literature. New York: Quebec Press 1999.

Nwahunanya, C. (1998). Theory, History and Criticism. Owerri; Corporate Impression. 
Nwaozuzu, G. I. "The Child as an Image of Innocence and Credulity in Igbo Folktales". Journal of Igbo Studies Association, Vol.1 Nsukka: Ifedimma Comm 2006.

Obiechina, E. N. Language and Theme. Washington D.C.: Howard University Press 1990.

Odunke Artists, Ojaadili i. Ibadan: University Press 1977.

Ogu, J.N. Creativity in Children's Literature in Africa. Ibadan: Heinemann 1992.

Okpewho The Oral Performance in African. Ibadan: Spectrum Books 1990.

Onyekaonwu, G. O. Verisimilitude Versus Realism: A Study of Igbo Fiction, Appreciation and Interpretation on Igbo Novel, Drama and Folktales" Unizik Journal of Arts and Humanity Nnamdi Azikiwe University. Awka. Faculty of Arts 2000.

Ubesie, T. Juo Obinna. Ibadan: University Press 1977.

Walton, K.L. "How Remote are the Functional World From the Real World. A Journal of Aesthetic and Art Criticism Vol.27, No.1 p. 11-23 1978.

Wordsworth, W. "Preface to Lyrical Ballads" in Kermode, E. et al (ed) The Oxford Anthology of English Literature. Vol. 2. New York: Oxford Press 1973. 